\title{
The Maladministration Alleviating Strategy in The Attempt of Facing Society 5.0 In Surakarta
}

\author{
Alya Raissa Abiel ${ }^{1}$, Kristina Setyowati ${ }^{2}$ \\ ${ }^{1}$ Universitas Sebelas Maret (email: alyaraissaabiel@gmail.com) \\ ${ }^{2}$ Universitas Sebelas Maret (email: kristina@staff.uns.ac.id)
}

\begin{abstract}
Maladministration still occurs frequently in some Indonesian areas, including Surakarta city. Various maladministration practices should be alleviated in Surakarta City, for the public service process to be performed maximally and thereby not taking the people's basic rights to receive the quality public service. Moreover, technology accessibility is getting higher and Indonesia is prepared for entering into society 5.0 Era expectedly more oriented to human beings (human centered). Therefore, this research aims to discuss the strategy of alleviating maladministration in Surakarta City in the attempt of dealing with Society 5.0 era. Then, this research employed a qualitative research method. The analysis technique used in this study was content analysis obtained through literature review. Considering the result of literature review, it can be seen various strategies applicable to alleviate maladministration in the attempt of dealing with Society 5.0 era: improving the quality of Human Resource; Expanding science research and development field; improving communication and technology infrastructure; discussion between practitioners; applying agile government concept; and the last, commitment, consistency, and collaboration between sectors in the attempt of dealing with Society 5.0.
\end{abstract}

\section{Keywords:}

Maladministration; society 5.0; strategy

\section{Introduction}

Indonesia is one of states with the densest populations in the world. Central Bureau of Statistic (BPS)' data resulting from population census in 2020 shows that the number of Indonesian populations is about 270.20 millions people, this number increases by 32.56 millions people compared with that in 2010. The large number of Indonesian populations requires the government to work harder in providing public service. Government in a state has three basic functions: maintaining home security and defense, organizing justice, and providing products not provided by the private (Adam Smith, 1976). Therefore, central government and local government plays very important role in fulfilling the principle of public service, including education, health, social-economic aspects, and etc. however, in 
reality not all attempts of improving the service taken by government run well, one of which is the accessibility of public service that has not been maximal, particularly in islands or remote areas. About 12 millions Indonesians are in danger of losing their basic rights due to the difficulty of accessing public service (kompas.com, 2016). In its development, Indonesia as a constitutional state has developed some regulations governing the process of organizing public service, one of which is Law No.25 of 2009 about Public Service. Thus, everything addressing public service has been governed in the Law. The enactment of Law No. 25 of 2009 about Public Service has revealed that government actually cares about the people's right and guarantees it. However, the existence of Law does not automatically ensure that the quality of public service provided by Indonesian people has been good. Some deviations in public service process is not taboo, moreover in Indonesia, because in fact many infringement practices are still found in the process of providing public service.

The infringement practice in public service is usually called "maladministration" (Hartono, et al., 2003) in Buku Panduan Investigasi (Investigation Guideline) for Indonesian Ombudsman defines maladministration generally as unreasonable behavior (including the postponement of service providing), impoliteness, and uncaring about the problem affecting an individual due to power abuse including arbitrary power use or the power used for unreasonable, unjust, intimidating and discriminative, and improper deeds based on entire or some of legal provisions or fact, not make sense or not based on unreasonable, unjust, oppressive, improper, and discriminative actions. In line with previous definition, maladministration as mentioned in Article 1 clause (3) of Law Number 37 of 2008 about RI's Ombudsman is unlawful behavior or deed beyond the authority, using authority for other purposes than the objective of authority, including negligence or indifference of legal obligation in organizing public service committed by provider, state, and government leading to material and/or immaterial losses to the people or the individual. From those definitions, it can be summarized that maladministration is a deviating or unlawful action committed by the provided of public service, thereby harming the people and inhibiting them from getting their rights as citizens. Citing the official page of ombudsman at ombudsman.go.id, it can be seen that in the last three years, the number of people complaint/report shows increase trend. About 10,075 complaints were received by RI's Ombudsman in 2018, 10,748 in 2019, and 12,742 in 2020. In line with the data available, there are at least 3 (three) putative 
maladministration practices often committed by the provider of public service: related to prolonged postponement $(31.57 \%)$, procedure deviation $(24.77 \%)$, and no service provided (24.38\%). Such condition indicates that maladministration practice in Indonesia still often occurs in some areas in Indonesia, including in Surakarta City.

Regional Inspectorate released the finding of nine serious cases related to financial management deviation in 2009. The nine cases involve nine persons, eight of which are civil servants. Based on data of Solo Regional Inspectorate, the cases occurring along 2009 makes the state/the region loses IDR 81.98 millions, with the state/region depositing obligation of IDR 415.03 millions. Then, in 2018 Ombudsman receive report related to putative maladministration practice committed by Surakarta City Government with the Right-to-Use (HP) land number 105. Furthermore, citing kompas.com in 2021, people are shocked with the news coverage on illegal levy collection committed by lurah in Surakarta City. Also, several infringements are committed by state civil apparatuses (ASN) in Solo City, in which about 63 state civil apparatuses of Surakarta City Government were absent in their first day work in 2018. Those facts indicate that maladministration practices are still found widely in Surakarta city. Maladministration practice is worsened with a disintegrated complaining facility. Citing tempo.com, Republic of Indonesia's Ombudsman (ORI) sees that Surakarta City Government has had many complaining channels related to public service. Unfortunately, the complaining channel has not been integrated yet. Thus, many people are still confused in expressing their aspiration and grievance.

A variety of maladministration practices in Surakarta should be alleviated, for the public service process to perform maximally, thereby not taking the people's basic rights to get the quality public service. Moreover, technology accessibility is getting higher and Indonesia is prepared for entering into society 5.0 Era expectedly more oriented to human beings (human centered). Meanwhile, Indonesia is currently still in industrial revolution 4.0 era, in which many adjustments and improvements should be made, particularly in the term of providing public service in Surakarta City, to prepare the state apparatus and the service public provider for dealing with the next era. Bureaucracy's incapability of supporting the creation of society 5.0 era is a very complex dynamic in Indonesia (Kumorotomo, 2019; Sugiono, 2020). Entering into society 5.0 era, Indonesian government should have thought of various strategies to anticipate various possibilities to occur as the implication of technology 
advance, people's life style and trend of world society. Currently, world society has prepared and led to Society 5.0 concept. If not prepared, Indonesia will be left behind in all areas, including when this maladministration practice is still entrenching. Therefore, the author is interested in discussing maladministration alleviating strategy in Surakarta City in the attempt of dealing with Society 5.0 era.

\section{Methods}

The research entitled The Maladministration Alleviating Strategy in Surakarta City in the Attempt of Facing Society 5.0 used a qualitative approach. A qualitative research method is the one used to study natural object, in which the author serves as key instrument, technique of collecting data was conducted in combination, data analysis was inductive in nature, and the result of qualitative research emphasizes more on meaning than on generalization (Sugiyono, 2007:1). The qualitative research aims to maintain the form and the content of human behavior and to analyze its qualities, rather than changing them into quantitative entities (Mulyana, 2008: 150). Furthermore, technique of analyzing used in this research is content analysis technique obtained through library study (literature review). Literature review is to study various references and findings of previous studies useful to get theoretical foundation concerning thee problem to be studied (Sarwono : 2006). Data source used in this research was secondary data source consisting of journal, book, written data coming from official web, and etc. Secondary source, according to Sugiyono (2012:141), is the data source obtained by means of reading, learning, and comprehending through other media originating from literatures, books, and documents. Research journals were obtained from some sources, for example through searching via google google scholar (https://scholar.google.co.id/), scopus (https://www.scopus.com) and etc. The criteria of article and journal used are literatures published in 2011-2021 both in Indonesian and English with the topic concerning maladministration and Society 5.0. Furthermore, the journal is taken as references and then analyzed. This research was conducted in Surakarta city for 30 days, from July 1 to 30, 2021. 


\section{Result and Discussion}

Table 1.

\section{Result of Literature Review}

\begin{tabular}{|c|c|c|}
\hline No & Source & Result or Finding \\
\hline 1 & $\begin{array}{l}\text { Good Public } \\
\text { Governance Towards } \\
\text { Society } 5.0 \text { In } \\
\text { Indonesia: A Review. } \\
\text { Psychology And } \\
\text { Education } \\
\text { Saksono, H., \& } \\
\text { Manoby, W. M. } \\
(2021)\end{array}$ & $\begin{array}{l}\text { - Indonesian public governance has not run optimally yet to encourage } \\
\text { the realization of Society } 5.0 \text { era. In addition, this research also gives } \\
\text { some recommendations related to the improvement of internet } \\
\text { infrastructure in order to reach remote areas, the preparation of legal } \\
\text { framework, cooperation between state institutions and corporations, } \\
\text { and the reinforcement of research-based innovative policy } \\
\text { supporting the creation of bureaucracy toward society } 5.0 \text { era in } \\
\text { Indonesia. } \\
\text { - Entering into society } 5.0 \text { era, Indonesian government should take } \\
\text { some anticipative measures because technology development and } \\
\text { trend world society are inevitable. World society has led to } 5.0 \\
\text { society, so that if unprepared, Indonesia will be left behind. } \\
\text { Responding to the Society 5.0 era, Indonesian National } \\
\text { Standardization Board has launched } 504 \text { National Standards (SNI). } \\
\text { - The preparation of Society 5.0 in Indonesia needs precondition } \\
\text { based on commitment, consistency, and collaboration of } \\
\text { multistakeholder, so that the presence of government improves, is } \\
\text { transparent, accountable, and useful to society (beneficiary society). } \\
\text { - Digitalization contributes to the created idealism in the GPG } \\
\text { implementer in line with the implementation of GCG throughout } \\
\text { public business lines (BUMN, BUMD, BLUD, and BUMDes). The } \\
\text { preparation for Society } 5.0 \text { will perform evenly and better if GPG is } \\
\text { conducted professionally through:1) improving infrastructure } \\
\text { related to telecommunication network, particularly community } \\
\text { internet reaching all rural areas in border, outermost, and at least } \\
\text { developed area also bordering on other states (3T-P); } 2 \text { ) preparing } \\
\text { legal protection for digital transformation and government } \\
\text { digitalization so that public service process becomes more } \\
\text { transparent and accountable; } 3 \text { ) expanding research and } \\
\text { development areas building on big data and artificial intelligence to } \\
\text { develop digital-based inclusive humanity along with the more } \\
\text { innovative public reinforcement based on policy evidence; } 4 \text { ) } \\
\text { creating added-value from the result of digital transformation } \\
\text { toward harmonious and humanistic society, and 5) the development } \\
\text { of high-performance GPG system in line with technology advance } \\
\text { and human dignity. }\end{array}$ \\
\hline 2 & $\begin{array}{l}\text { Pelayanan Publik } \\
\text { Melalui Electronic } \\
\text { Government: Upaya } \\
\text { Meminimalisir Praktek } \\
\text { Maladministrasi Dalam } \\
\text { Meningkatan Public } \\
\text { Service } \\
\text { Holle,Erick (2011) }\end{array}$ & $\begin{array}{l}\text { - Maladministration in various forms and types as aforementioned can } \\
\text { be minimized or even can be removed when public service is no } \\
\text { longer provided in face-to-face or direct contact, but electronically or } \\
\text { called e-services. Viewed from Indonesian context, it will be in } \\
\text { contrast to the condition in Japan. Indonesia is expected to experience } \\
\text { demographic bonus period in 2030-2040, in which the number of } \\
\text { productive age populations is higher than the non-productive ones } \\
\text { (Azizah \& Indartono, 2019). }\end{array}$ \\
\hline
\end{tabular}




\begin{tabular}{|c|c|c|}
\hline No & Source & Result or Finding \\
\hline 3 & $\begin{array}{l}\text { Penguatan Reformasi } \\
\text { Birokrasi Menuju Era } \\
\text { Society } 5.0 \text { di Indonesia } \\
\text { (Yasa,Andika.,Suswa } \\
\text { nta.,Rafi,M.,dkk, } \\
\text { 2021) }\end{array}$ & $\begin{array}{l}\text { - The principles of good public governance can be the parameter of } \\
\text { governmental modernization process toward Society 5.0, but the } \\
\text { principles are also affected by environment, politics, economy, and } \\
\text { culture (Alsharari, 2019; Grindle, 2007) } \\
\text { - The change of HR's mindset and mental attitude to modernity in } \\
\text { the bureaucracy of society 5.0, in the future we should be able to } \\
\text { provide bureaucracy with sustainable, effective, humanistic, } \\
\text { disciplined, and competent work cultures (Sihite, 2018). } \\
\text { - Bureaucracy of society } 5.0 \text { in addition to having knowledge and } \\
\text { skill advantages in utilizing technology, should be superior in } \\
\text { mental attitude. HR professionalism of apparatuses not only should } \\
\text { be limited to the skill of using technology and high knowledge, but } \\
\text { should also be compensated with moral ethical behavior. }\end{array}$ \\
\hline 4 & $\begin{array}{l}\text { Pembelajaran Era } \\
\text { Disruptif Menuju } \\
\text { Masyarakat } 5.0 \\
\text { (Suryadi, 2020) }\end{array}$ & $\begin{array}{l}\text { - To prepare Superior Human Resource in Industrial Revolution } 4.0 \\
\text { era toward Society 5.0, Education Intervention is required, involving } \\
\text { curriculum, educator and teaching staff, infrastructure, funding, and } \\
\text { education management. } \\
\text { - The learning in industrial revolution } 4.0 \text { era toward Society } 5.0 \text { in } \\
\text { Education Management perspective is conducted by means of } \\
\text { integrating various aspects contributing to the achievement of } \\
\text { national education objective. }\end{array}$ \\
\hline 5 & $\begin{array}{l}\text { Membayangkan } \\
\text { Pemerintahan Agile: } \\
\text { Belajar dari Konsep } \\
\text { Masyarakat Jepang } 5.0 \\
\text { dan Tantangan } \\
\text { Administrasi Publik di } \\
\text { Negara Berkembang } \\
\text { (Wahyudi } \\
\text { Kumorotomo,2019) }\end{array}$ & $\begin{array}{l}\text { - Unfortunately, policy makers and public manager in Indonesia } \\
\text { generally have not been aware of the need for the change of public } \\
\text { administration paradigm under disruptive environment. Although } \\
\text { many scholars and public officials have talked about the need for } \\
\text { agile government, a comprehensive approach at national level to } \\
\text { formulate adequate strategy, to connect it to actual performance in } \\
\text { public organization and to improve national competitiveness has not } \\
\text { been applied yet. } \\
\text { - Therefore, to deal with the challenge of improving competitiveness } \\
\text { and efficiency in public organization, a new discourse arises about } \\
\text { what is called "agile government", a common recipe to create more } \\
\text { professional, fast, and responsive public institution. } \\
\text { - Therefore, the need for creating agile government and more } \\
\text { responsive public administration should involve not only Ministry } \\
\text { of State Apparatus Utilization and Bureaucratic Reform (Kemenpan } \\
\text { RB) but also all politicians, governmental institutions, think-tank, } \\
\text { university practitioner, and public. Intensive and productive } \\
\text { discussion between public administration practitioners will be a } \\
\text { good beginning for cooperating with other society elements. The } \\
\text { importance of connecting technology under human-centered } \\
\text { "super-smart society" should be comprehended, not only at } \\
\text { conceptual level but also at practical level inside and outside } \\
\text { government. }\end{array}$ \\
\hline 6 & $\begin{array}{l}\text { Upaya Pencegahan } \\
\text { Maladministrasi } \\
\text { Pelayanan Publik Oleh } \\
\text { Ombudsman Republik } \\
\text { Indonesia di Provinsi } \\
\text { Sumatera Barat (Putri, }\end{array}$ & $\begin{array}{l}\text { - There are two attempts having been taken by West Sumatera's } \\
\text { Ombudsman to prevent maladministration from occurring in public } \\
\text { service. Firstly, preemptive attempt is the one conducted to inculcate } \\
\text { values and norms to public service recipients to make them } \\
\text { understand and to avoid maladministration. }\end{array}$ \\
\hline
\end{tabular}




\begin{tabular}{|c|c|c|}
\hline No & Source & Result or Finding \\
\hline & $\begin{array}{l}\text { Felicya Astwilanda } \\
\text { dan Adnan, M. } \\
\text { Fachri, 2020) }\end{array}$ & $\begin{array}{l}\text { - Secondly, preventive attempt is the one conducted to make the } \\
\text { public service provider understand and provide service according to } \\
\text { the enacted Law to prevent maladministration from occurring. }\end{array}$ \\
\hline 7 & $\begin{array}{l}\text { Pentingnya } \\
\text { Perencanaan } \\
\text { Manajemen Pada Era } \\
\text { Society 5.0 (Gumulya, } \\
\text { Devanny ,2021) }\end{array}$ & $\begin{array}{l}\text { - From the figure above, it can be seen that technology is a factor } \\
\text { encouraging the emergence of Society 5.0, but it is not enough. } \\
\text { Without management planning made using participatory method } \\
\text { involving all parties, including government, private, and society, } \\
\text { and commitment by all parties to implement it, these fruits of Society } \\
5.0 \text { will never be achieved. } \\
\text { - The challenge of management planning in Society } 5.0 \text { era is that } \\
\text { human rather than AI should remain to serve as decision maker. } \\
\text { Therefore human being should have future vision, creativity, and } \\
\text { high imagination in setting up the objective and developing plan } \\
\text { based on the result of AI analysis. Technology advance in Society } 5.0 \\
\text { can exert negative effect. For example, it can replace human beings } \\
\text { in some jobs, human beings become isolated, and data abuse. But all } \\
\text { of these can be avoided if we have society vision like what we dream } \\
\text { of in the future and the initiative we can take to support the vision } \\
\text { without drifted in the transformation stream. }\end{array}$ \\
\hline 8 & $\begin{array}{l}\text { Big Data: Apa } \\
\text { Implikasinya terhadap } \\
\text { Kebijakan Sektor Publik } \\
\text { di Era Society 5.0? } \\
\text { (Rahmanto, Fajar ., } \\
\text { Pribadi, Ulung ., } \\
\text { Priyanto, Agus,2021) }\end{array}$ & $\begin{array}{l}\text { - Society } 5.0 \text { is important to be realized through science research and } \\
\text { development supported with technology and human resource } \\
\text { competency to contribute to various public sectors. } \\
\text { - Policy makers in Society } 5.0 \text { era not only should have high } \\
\text { technology knowledge but should also be compensated with moral } \\
\text { and ethical behavior. }\end{array}$ \\
\hline
\end{tabular}

Maladministration practices occurring in Surakarta is a small portrait of fraud occurring in Indonesian bureaucratic body. Referring to some maladministration cases occurring in Surakarta City, it can be explained that the causes of maladministration in Surakarta City are, among others: the low quality of human resource morality, low integrity, and technology system problem. A variety of maladministration practices in bureaucratic body should be alleviated. From some journals referred to, it can be seen some strategies to alleviate the maladministration problem in Surakarta. The first strategy is to improve human resource quality. The improvement of human resource quality is something important, because bureaucratic wheel, administration and public service should always be undertaken by human aspect, in this case usually called human resource. Human resource quality plays an important role and serves all at once as indicator of whether or not the public service has run well. It is well-established that every deviating behavior (maladministration) results from incompetent human resource quality. The improvement of human resource is an early step 
that can be taken to reform all maladministration system that has entrenched. Managerially, as a capital, resource should be developed continuously, thereby can contribute to the achievement of organizational objective. It can be said "Only with the right personnel put on the right position getting training, equipment, infrastructure, incentive, and accountability for working effectively, will an organization be very likely successful". U.S. Office of Personnel Management, 1999:3). The attempt of improving human resource quality can be accomplished through some methods. The quality of human resource, according to Danim (1996:44), is a human resource fulfilling the criteria of physical quality and health, intellectual quality (knowledge and skill), and mental spiritual quality.

The improvement of HR quality can be accomplished through training character building or inculcating values and norms, and reinforcing mentality and morality inside ASN (state civil apparatus) and public service recipients (community). It is intended to make human resource have awareness and strong guideline to keep providing service according to the existing standard and ethics. Furthermore, viewed from community aspect, when people are educated about values and norms concerning good public service mechanism, people can avoid maladministration practice committed by ASN, because basically people has rights to complain when the service provided is not compatible to the standard existing. In addition, when values and norms are successfully internalized into ASNs, they are expected to control attitude and to keep away from maladministration practices, so that maladministration practice can be suppressed. The attempt of improving human resource quality focuses not only on mentality and morality of human resource but also on knowledge aspects.

The strategy to improve human resource knowledge and skill can be taken through improving education management, including evaluation of education curriculum, teaching staff, supporting facilities, funding, and education management, and through integrating aspects contributing to the achievement of national education objective. It is in line with the finding of previous study (Suryadi, 2020) on the Learning in Disruptive Era toward Society 5.0. If education management has run well and has high quality, the aspect of human resource knowledge is guaranteed for its quality. If mentality, morality, and knowledge aspects of HR have been quality, HR can adapt to era and technology development existing. Then, the second strategy is to expand science research and development area supported with technology competency and human resource. Science research and development should be 
conducted to give contribution, reference, and recommendation to improve a variety of public service sector, to make the public service provided have higher quality and far away from maladministration practices. Research should be conducted continuously to project what action the government can take to face the next era, related to the development of Society 5.0. In the presence of real research based on factual data, government is expected to take action right on target, to make various quality and innovative policies to support technology development and the creation of legal protection for digital transformation and digitalization in government sector. It is well established that time develops continuously, and technology is a part of life inseparable from human life. Thus, government should be able to make innovative policy in order to create added-value from digital transformation result toward harmonious and humanistic society.

The values of society 5.0 will not be achieved if government does not have capability of making innovative and dynamic policy. Referring to the present reality, the rapid technology development has brought Indonesia to the new era, when there are at least four startups with over US $\$ 1$ billion value that have developed for about five years. These startups are, among others: Tokopedia, Gojek, Bukalapak, and Traveloka. The emergence of various startups as the consequence of technology development has required the government to provide legal protection to the existence of startups in Indonesia, including the unicorn startup. Government is a single institution with power, authority, and legal resource to balance the advantage of new business model, thereby providing strong, equivalent, and sustainable growth and prosperity to the people. The problem is that government and its apparatuses always respond late to the quickly-changing policy environment (Kumorotomo, Wahyudi 2019). The government's poor capability of being present amid the transformation is due to its poor understanding on new perspective and challenge in the digital development environment existing. Government's failure in transformation will inhibit a state's advance to exist in the further time development. Therefore, science research and development is a good strategy in order to be the reference in providing innovative and adaptive policy to support the technology development occurring. The third strategy to minimize maladministration to enable the public service in Indonesia to be prepared for facing Society 5.0 era is through repairing and improving communication and technology network infrastructure evenly. In this case, Surakarta City government should be able to provide adequate communication 
technology infrastructure, in order to support the transformation toward society 5.0. Without inadequate preparation of infrastructure, the transformation process occurring will be inhibited. The attempt of improving technology and communication network is related to not only physical infrastructure but also legal protection underlying digital transformation and government digitalization should be prepared well and systematically, in order not to inhibit the government's innovative active in the future. The improvement of technology and communication infrastructure should be done to reform the public service process; it means that all public service affairs can be done innovatively through e-service or other digital platforms. Thus, it can minimize the face-to-face public service and avoid the maladministration practice in public service providing process. Nearly all studies conducted by public service observers conclude that public service through direct contact is vulnerable to maladministration practice, the practice deviating from administration ethic or an administration practice far from the achievement of administration objective (Holle, 2011). It is well established that the factor causing maladministration practice always relate to the service provided directly. Direct contact-based Public service will invite special treatments or subjectivity leading to the deviation from administration stipulation, and thereby triggering the maladministration practice. For example, there is an individual coming to public institution and incidentally he has kinship with one of personnel in the institution. Therefore, automatically public servant will prioritize the individual. Such practice is no strange in Indonesia, including in Surakarta City. Hence, infrastructure reform is the key to minimizing direct contact-based public service in order to suppress maladministration.

The fourth strategy is discussion between administration practitioners or between administration practitioner and other practitioners to provide a strategy or other output useful to improve public service process. Discussion generates various new thinking, so that the presence of discussion can enrich the people and the stakeholders' perception on public service issues occurring. The next strategy is to create agile government. This emergence of agile government narration builds on bureaucratic/public service condition in Indonesia tending to be slow and elaborate. Citing the finding of research entitled "Imagining Agile Government: Learning from the concept of Japan Society 5.0 and Public Administration Challenge in Developing Countries" conducted by Wahyudi Kumorotomo, 2019, it can be said that on average Indonesian standard procedure of getting business permit is too elaborate 
compared with that in OECD or other East Asian states. Singapore always occupies the first rank related to the licensing process in ASEAN region. Investment licensing in Singapore can be completed within 7 (seven) weekdays. Meanwhile, it can be processed within about 90 weekdays or 3 months in Indonesia. Therefore, to remove the gap and as an attempt of improving efficiency in public organization, the discourse of agile government is required. In agile governance concept, there are at least six principles: good enough governance, business driven, human focused, based quick wins, systemic and adaptive approach and simple design and continuous refinement (Luna, 2015). Good enough governance means that in managing an organization, the background of organization should be taken into account. Furthermore, business-driven principle is every decision and action always business oriented. Human Focused principle is defined as the need for the space in public governance for the people (community) to participate. Then, every input existing will be appreciated. Principle of Based on quick wins means that a success that has been achieved quickly should be an incentive in order to get output better before. Then, the principle of systematic and adaptive approach is the quick and systematic change needed by a team that can be increase their ability, particularly intrinsic ability. Simple design and continuous refinement is the team's ability of making simple design and required to provide output quickly and better. Although out of the six principles, only several of them can be applied, the agile governance concept can be used to find quick answer and to create sustainable effect on the condition expected. This agile governance is required to create more professional, quicker, and more responsive public institution. The slow and elaborate licensing process and other public service process in Indonesia generate a change for the public servants to do maladministration practice. Agile government discourse gives answer to the restlessness occurring so far in public service process.

The implementation of agile government should always run harmoniously with the human resource existing, in which policy makers in Indonesia should always be aware that in this disruptive era, they are required to understand the need for the change of paradigm in public administration, so that it is inline with the time development. Then, public administrators or policy makers are required to actualize agile government into the public organization, so that the discourse of agile government is not only limited to concept, but is implementable as well, in order to improve a region's or a nation's competitiveness in the 
quality public service free of maladministration practice. The realization of agile government in bureaucratic body in many Indonesian regions, including Surakarta City will bring public institution to the more professional, fast, responsive one free of maladministration practice, and thereby can create the quality public service to society. The sixth strategy relates to commitment, consistency, and collaboration of stakeholders to create the high-quality public service system corresponding to the stipulation enacted by utilizing every development of technology existing. Commitment, according to Meyer and Allen (1991, in Soekidjan, 2009), is an individual's strong acceptance to organizational objectives and values, and the individual attempts, works, and has strong will to stay in the organization. Essentially, commitment relates to each individual's sincerity in undertaking his responsibility. Then consistency relates to an individual's action accompanied with various directed objective. Whatever the condition, if public servant, community, and stakeholder have good consistency to realize the good public service system, such attempt will remain to be taken. Furthermore, collaboration is something relating to cooperation with many parties for the sake of creating supportive condition. Without collective commitment, consistency, and collaboration, the strategies explained cannot run well. Basically, technology development is the factor generating the presence of Society 5.0. Technology development should run in line with the management planned using participatory method, thereby involving all parties, including government, private, and ommunity, and the commitment by all parties to implement it. If all strategies are implemented well, the public service condition in Indonesia, particularly in Surakarta City, is expected to be free of maladministration practice. Thus, bureaucratic condition in Surakarta City will be more prepared for facing the new era, Society 5.0 era that is human centered. The concept of Society 5.0 will be realized difficulty when bureaucracy condition in Indonesia still indicates maladministration practices and other fortress inhibiting the realization of Society 5.0. Basically, Society 5.0 is a transformation of information community concept present based on the civilization in previous era and aiming to realize a prosperous human-centered community in which everyone will enjoy life maximally (Fukuyama, 2018; Harayama, 2016).

In addition, the concept of Society 5.0 aims to distribute economic and technology accesses evenly to all classes of society, in order to create welfare in the society. The even distribution of technology as the continuation of industrial society 4.0 era is conducted by considering humanity aspect continuously in order to provide a strategy to solve social 
problem. The concept of Society 5.0 is expected to integrate physical and cyber spaces in balance (Salgues, 2018). Thus, society 5.0 era can be understood as one of society life forms that combining data through information technology to encourage the improvement of human resource intelligence in developing various implementable opportunities based on humanity aspect in order to solve various social problems. Society 5.0 focuses on human components by keeping using artificial intelligence like tool/media. Internet serves not only as information but also to live life in society 5.0 era, or era in which all technologies are the part of human itself. Technology development can minimize the gap in human beings and economic problem in the future, in which this era offers the balance-centered community (Suryadi, 2020). As the initiator of Society 5.0 concept, Japan has defined concept of Society 5.0 in many things, including: (1) the significance of technology development, but community's participation becomes the material of consideration in the industrial revolution 4.0 incidence, (2) Society 5.0 offers a human-centered, it can be explained that the two definitions can be achieved through the strategy of improving and developing human resource quality. This improvement of human resource quality can be accomplished through reinforcing mentality, morality, and knowledge aspect. The creation of good and competent human resource quality will improve the ability and the role of human resource in life. Thus, it minimize the significant shift of role from human beings to technology and the community still can have control over life, despite the presence of technology aid. (3) Society 5.0 balances Economic Advance and Social Problem Solving through a system connecting Cyber Space and Real World. This definition is relevant when the strategy of developing science, improving communication and technology network infrastructure and discussion between practitioners is implemented. (4) Society 5.0 is no longer a capital but data connecting and activating everything. The fourth definition can be accomplished through research and development strategy, through discussion between public administrator practitioners and between public administrator practitioner and other practitioners to provide other strategies or outputs useful to improve the public service process and through commitment, consistency, and collaboration with multistakeholder. (5) Helping filling in the gap between the rich and the poor, (6) Medical and educational service, from primary level to high education will reach small villages. Meanwhile the fifth and the sixth definition can be realized when public service is free of maladministration practices harming the community, so that all strategies should be 
implemented well. It is in line with Keindanren's argument (Japan Business Federation, 2016, p. 14, in Serpa, 2018) that a number of mechanism elements in individual state governments is required to realize the objective of Society 5.0, including 1) the formulation of national strategy and the integration of government communication system; 2) the development of law toward the application of new technology; 3) the establishment of knowledge foundation; 4) dynamic participation of all citizens in new economy and community; 5) integration of technology and community. The strategy of alleviating maladministration is illustrated in the figure below.

Figure 1.

\section{Framework of Maladministration Alleviation}

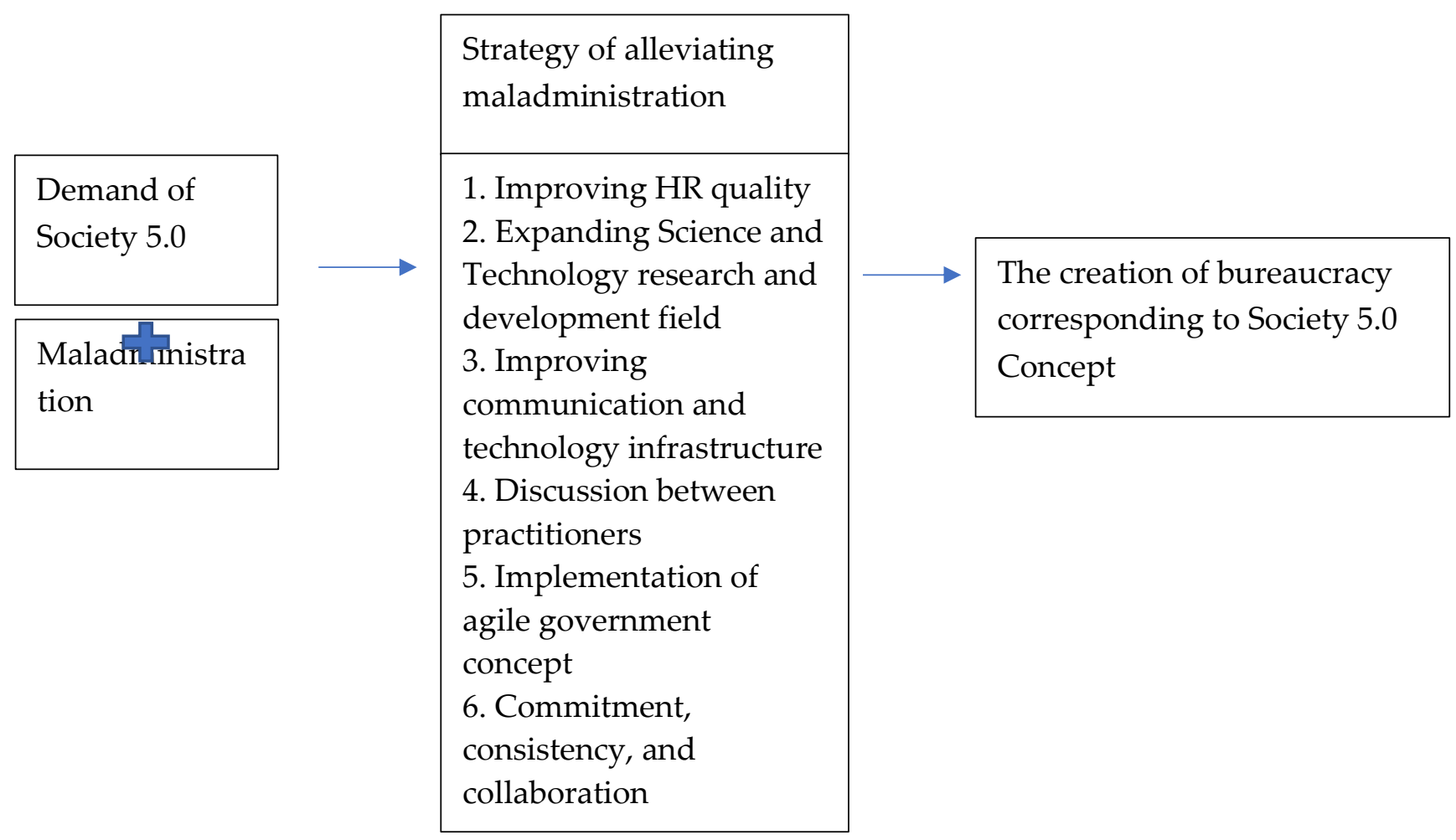

\section{Conclusion}

The presence of Society 5.0 concept has required many regions throughout world, including Surakarta City, to keep transforming. Maladministration practices found widely in Surakarta City has inhibited the city to realize the concept Society 5.0. Therefore, to prepare bureaucratic condition free of maladministration in Indonesia, particularly in Surakarta City, 
several strategies are required. The first one is to improve the quality of human resource, including mentality, morality, and knowledge aspects. If mentality, morality, and knowledge aspects of human resource have high quality, human resource can adapt to era and technology development existing. The next strategy is to expand science research and development. Science research and development should be done to give contribution, reference, and input to improve various public service sectors, to make the public service have higher quality and far from maladministration practices.

Research should be conducted continuously in order to project what actions the government can take to face the next era, related to the development of Society 5.0. The third strategy is to improve communication network and technology infrastructure evenly in order to support the change into Society 5.0. The fourth strategy is to hold discussion between public administrator practitioners and between public administrator practitioner and other practitioner to provide other strategies or outputs useful to improve public service process. Some other strategies taken to alleviate the problem of maladministration in bureaucratic body for the sake of preparing the self toward Society 5.0 era is to implement agile government concept and commitment, consistency, and collaboration of multistakeholder to create the quality public service system according to the stipulation enacted by utilizing each of technology development existing. The creation of strategy to alleviating maladministration will guide bureaucracy in Indonesia to the more prepared, more professional, and better condition. Thus, the people's rights to get public service are not harmed by maladministration practices. The strategies are expected to bring Indonesian bureaucratic condition to more transformative and adaptive one, thereby can adapt to Society 5.0.

\section{References}

Akny, Aldenila Berlianti. (2014). Mewujudkan Good Governance Melalui Reformasi Birokrasi Di Bidang Sdm Aparatur Untuk Peningkatan Kesejahteraan Pegawai. Jurnal Jejaring Administrasi Publik. (1), 416-427

Apriliyanti, Kiki., Latif, M. Daud Irsya., dan Dyah Mutiarin. (2021). Narasi Budaya Arek Suroboyo dan Pandemi Covid-19: Sebuah Perspektif Agile Governancedi Kota

$\begin{array}{lllll}\text { Surabaya. Jurnal } & \text { Transformative, } & 7 & \text { (1), } & \text { DOI }\end{array}$ 10.21776/ub.transformative.2021.007.01.1 
Effendi, Haris. (2018). 63 ASN Pemkot Solo Absen Hari Pertama Masuk Kerja. July 15 , 2021. retrieved from https://metrojateng.com/63-asn-pemkot-solo-absen-hari-pertamamasuk-kerja/

Gumulya, Devanny. (2021). Pentingnya Perencanaan Manajemen Pada Era Society 5.0. Prosiding Seminar Nasional Desain Dan Arsitektur (Senada). retrieved from Https://Senada.Idbbali.Ac.Id/

Halim, Farhan Rahmawan., Astuti, Feni., dan Umam, Khaerul. (2021). mplementasi Prinsip Agile GovernanceMelalui Aplikasi PIKOBAR di Provinsi Jawa Barat. Kolaborasi : Jurnal Administrasi Publik, 7 (1), 48-67. DOI https://doi.org/10.26618/kjap.v7i1.4736

Holle, Erick S. (2011). Pelayanan Publik Melalui Electronic Government: Upaya Meminimalisir Praktek Maladministrasi Dalam Meningkatan Public Service. Jurnal Sasi, 17 (3), 21-30. retrieved from https://fhukum.unpatti.ac.id

Kumorotomo,Wahyudi. (2019). Envisioning Agile Government: Learning From The Japanese Concept Of Society 5.0 And The Challenge Of Public Administration In Developing Countries. Proceedings Of The Annual Conference Of The Indonesian Association For Public Administration (Iapa 2019). retrieved from Https://Www.AtlantisPress.Com/Proceedings/Iapa-19/125935450

Luna, A. J. H. de O. (2015). Agile Governance Theory. May, 601. retrieved from https://repositorio.ufpe.br/handle/123456789/15494

Mustaghfiri, Mohammad Haidar ., Susiloadi, Priyanto. (2021). Kualitas Pelayanan Penerbitan Izin Mendirikan Bangunan Di Dinas Penanaman Modal Dan Pelayanan Terpadu Satu Pintu Kota Surakarta. Jurnal Wacana Publik, 1 (1), 99-107

Ombudsman Perwakilan Jawa Tengah. (2018). Polemik Lahan HP 105, Dugaan Maladministrasi Pemkot Solo Diselidiki Ombudsman. July 15 ,2021. retrieved from https://www.ombudsman.go.id/perwakilan/news/r/pwk--polemik-lahan-hp-105dugaan-maladministrasi-pemkot-solo-diselidiki-ombudsman--

Ombudsman Republik Indonesia. (2020). Laporan Tahunan 2020 Mengawal Pelayanan Publik di mas COVID-19. July 21 , 2021. retrieved from https://ombudsman.go.id/news/r/ombudsman-ri-luncurkan-laporan-tahunan-2020 
Putri, Felicya Astwilanda ., Adnan, M. Fachri. (2020). Upaya Pencegahan Maladministrasi Pelayanan Publik Oleh Ombudsman Republik Indonesia Di Provinsi Sumatera Barat. Jurnal Mahasiswa Ilmu Administrasi Publik(Jmiap), 2 (1) , 33-41

Saksono,Herie ., Manoby, Worry Mambusy. (2021). Good Public Governance Towards Society 5.0 In Indonesia: A Review. Psychology And Education Journal, 58 (2), 4499-4511

Sari, Meri Enita Puspita. (2018). Peran Pemerintah Dalam Penyediaan Akses Pelayanan Publik. Jurnal Trias Politika, 2 (1), 1-12

Solo Pos. (2009). Inspektorat Solo temukan 9 kasus penyimpangan pengelolaan keuangan. July 21 ,2021. retrieved from https://www.solopos.com/inspektorat-solo-temukan-9kasus-penyimpangan-pengelolaan-keuangan-10163

Suryadi. (2020). Pembelajaran Era Disruptif Menuju Masyarakat 5.0 (Sebuah Telaah Perspektif Manajemen Pendidikan). Prosiding Seminar Nasional Pendidikan Program Pascasarjana Universitas Pgri Palembang 10 Januari 2020. retrieved from Https://Jurnal.Univpgri-

Palembang.Ac.Id/Index.Php/Prosidingpps/Article/View/3783

Utami, Wijayanti Setyo Dan Suryanto. (2013). Indeks Kepuasan Masyarakat Pada Pelayanan Kantor Kecamatan Di Surakarta, Indonesia. Jurnal Ekonomi Dan Studi Pembangunan, 14 (2), 174-184

Wahyudi, Rodi., Malek, Jalaluddin Abdul., Dan Aziz, Azmi. (2014). Faktor Penyebab Perilaku Maladministrasi Birokrasi Di Institusi Pemerintah Di Kota Pekanbaru Provinsi Riau. Jurnal El-Riyasah, 5 (2), 1-10. Doi: Http://Dx.Doi.Org/10.24014/Jel.V5i2.648

Wahyudi, Rodi., Malek, Jalaluddin Abdul., Dan Aziz, Azmi. (2015). Perilaku Maladministrasi Birokrasi Dalam Pelayanan Publik Di Di Kota Pekanbaru, Provinsi Riau: Faktor Penyebab Dan Solusinya. Jurnal Administrasi Publik, 12 (1), 55-70.

Yasa,Andika., Suswanta., Dkk. (2021). Penguatan Reformasi Birokrasi Menuju Era Society 5.0 Di Indonesia Strengthening Bureaucratic Reform Towards Society 5.0 Era In Indonesia. Nahkoda: Jurnal Ilmu Pengetahuan, 20(1), 27-42. Doi : 10.35967/Njip.V20i1.139 